\title{
Berat Badan dan Panjang Badan Lahir Meningkatkan Kejadian Stunting
}

\author{
Novi Hidayati \\ Akademi Kebidanan Bhakti Pertiwi Pemalang \\ Novi.hidayati.1411@gmail.com
}

\begin{abstract}
Abstrak. Kabupaten Pemalang termasuk 10 Kabupaten prioritas penanganan stunting. Hasil pengumpulan data dari kader kesehatan di Desa Jebed Utara, terdapat 12 batita stunting (11,7\%). Penelitian ini merupakan penelitian survei analitik dengan desain penelitian cross sectional. Penelitian ini dilaksanakan di Desa Jebed Utara Kecamatan Taman Kabupaten Pemalang selama bulan Februari Maret 2020. Populasi dalam penelitian ini adalah seluruh anak usia 13-36 bulan di desa Jebed Utara yang berjumlah 240 anak. Sampel dalam penelitian ini adalah sebanyak 103 responden dengan menggunakan teknik random sampling. Variabel yang diteliti adalah Berat badan lahir rendah, Panjang badan lahir dan stunting. Analisis bivariat menggunakan uji chi square (CI=95\%, $\alpha=0,05)$. Terdapat sebanyak 22,3\% batita memiliki berat badan lahir rendah dan terdapat sebanyak 20,4\% batita lahir dengan panjang $<48 \mathrm{~cm}, 79,6 \%$ batita lahir dengan panjang normal. Dari total sampel 103 Terdapat sebanyak 12 Batita yang berstatus stunting Hasil uji statistik antara BBLR dan stunting menunjukkan nilai $p=0,966(p>0,05)$. Tidak terdapat hubungan antara berat badan lahir dengan stunting pada batita di Desa Jebed Utara Kecamatan Taman Kabupaten Pemalang. Sementara hasil uji statistic antara panjang badan anak dengan stunting menunjukan nilai $p=0,000$. Terdapat hubungan antara panjang badan anak dengan stunting di Desa Jebed Utara Kecamatan Taman Kabupaten Pemalang.
\end{abstract}

Kata kunci: Berat badan lahir, Panjang badan lahir, Stunting, Batita

\section{Body Weight and Birth Length of Toodlers is related with Stunting}

Abstrack. Pemalang Regency is one of the 10 priority districts for handling stunting. The results of data collection from health cadres in Jebed Utara Village, there were 12 stunting toddlers (11.7\%). This research is an analytic survey research with cross sectional research design. This research was conducted in Jebed Utara Village, Taman Subdistrict, Pemalang Regency during February - March 2020. The population in this study were all children aged 13-36 months in North Jebed Village, totaling 240 children. The sample in this study were 103 respondents using random sampling technique. The variables studied were low birth weight, birth length and stunting. Bivariate analysis used the chi square test $(C I=95 \%, \alpha=$ $0.05)$. There are $22.3 \%$ of toddlers have low birth weight and there were $20.4 \%$ toddlers born with a length $<48 \mathrm{~cm}, 79.6 \%$ toddlers born with normal length. There are as many as 12 toddlers who are stunting. The results of statistical tests between $L B W$ and stunting showed $p$ value $=0.966$ ( $p>0.05)$. There is no relationship between birth weight and stunting in toddlers in Jebed Utara Village, Taman Subdistrict, Pemalang Regency. Meanwhile, the statistical test results between the child's body length and stunting showed the value of $p=0.000$. There is a relationship between the length of the child's body and stunting in Jebed Utara Village, Taman Subdistrict, Pemalang Regency.

Key words: Birth weight, birth length, stunting, toddlers

\section{Pendahuluan}

Stunting masih menjadi permasalahan besar untuk sebagian besar negara di dunia. Pada tahun 2017, sebanyak $22,2 \%$ atau sekitar 150,8 juta balita di dunia mengalami stunting. Lebih dari setengah balita stunting di dunia berasal dari Asia (55\%), sedangkan lebih dari sepertiganya (39\%) tinggal di Afrika. 
Data prevalensi balita stunting yang dikumpulkan World Health Organization (WHO), Indonesia berada dalam urutan ke-3 dengan prevalensi tertinggi di regional Asia Tenggara/South-East Asia Regional (SEAR). Rata-rata prevalensi balita stunting di Indonesia tahun 20052017 adalah $36,4 \%$ (WHO, 2018)

Gizi pada masa kehamilan menentukan tumbuh kembang saat masa janin dalam kandungan. Salah satu faktor risiko yang mempengaruhi kejadian stunting pada anak balita adalah riwayat berat badan lahir rendah (BBLR). Menurut Proverawati dan Ismawati (2010) bayi dengan BBLR akan tumbuh dan berkembang lebih lambat karena pada bayi dengan BBLR sejak dalam kandungan telah mengalami retardasi pertumbuhan intera uterin dan akan berlanjut sampai usia selanjutnya, setelah dilahirkan akan mengalami pertumbuhan dan perkembangan yang lebih lambat dari bayi yang dilahirkan normal, dan sering gagal menyusul tingkat pertumbuhan yang seharusnya dia capai pada usianya setelah lahir. Bayi BBLR juga mengalami gangguan saluran pencernaan, karena saluran pencernaan belum berfungsi, seperti kurang dapat menyerap lemak dan mencerna protein sehingga mengakibatkan kurangnya cadangan zat gizi dalam tubuh. Akibatnya pertumbuhan bayi BBLR akan terganggu (Proverawati, A \& Ismawati, C, 2010).

Panjang lahir menggambarkan pertumbuhan linier bayi selama dalam kandungan. Ukuran linier yang rendah biasanya menunjukkan keadaan gizi yang kurang akibat kekurangan energi dan protein yang diderita waktu lampau (Supariasa \& Fajar, 2012). Masalah kekurangan gizi diawali dengan perlambatan atau retardasi pertumbuhan janin yang dikenal sebagai Intra Uterine Growth Retardation (IUGR). Di negara berkembang kurang gizi pada pra-hamil dan ibu hamil berdampak pada lahirnya anak yang IUGR dan Berat Badan Lahir Rendah (BBLR), kondisi IUGR hampir separuhnya terkait dengan status gizi ibu selain itu faktor lain dari penyebab terjadinya IUGR ini adalah kondisi ibu dengan hipertensi dalam kehamilan (Cesar , Linda, Caroline, Pedro, \& Reyna, 2008). Panjang lahir bayi akan berdampak pada pertumbuhan selanjutnya, seperti terlihat pada hasil penelitian Anugraheni \& Kartasurya (2012) yang mendapatkan hasil bahwa bayi yang lahir dengan panjang lahir rendah memiliki risiko 2,8 kali mengalami stunting dibanding bayi dengan panjang lahir normal (Anugraheni \& Kartasurya, 2012).

Berdasarkan studi pendahuluan di desa Jebed Utara Kecamatan Taman, Kabupaten Pemalang dari 103 batita yang diukur status gizinya ada 12 batita $(11,7 \%)$ yang memiliki status gizi pendek (Stunting). Meskipun Angka ini lebih rendah dibandingkan dengan prevalensi stunting di pemalang $12,8 \%$, angka prevalensi stunting pada Batita di Provinsi Jawa Tengah sebesar $30 \%$ dan juga lebih rendah dari angka prevalensi nasional sebesar $37,2 \%$ namun jika Stunting dibiarkan dapat menyebabkan kerusakan permanen. Hal ini terjadi bila seorang anak kehilangan berbagai zat gizi yang penting untuk tumbuh kembangnya, kekebalan tubuh, dan perkembangan otak yang optimum. Artikel ini memberikan informasi faktor berat badan dan panjang lahir meningkatkan dengan kejadian stunting pada anak usia batita.

\section{Metode}


Jenis penelitian yang digunakan adalah survei analitik dengan menggunakan rancangan penelitian cross sectional, yaitu suatu penelitian untuk mempelajari dinamika korelasi antara faktor sebab dengan akibat yang terjadi pada objek penelitian dan dikumpulkan dalam waktu yang bersamaan (Notoatmodjo,2018). Populasi dalam penelitian ini adalah seluruh anak usia batita di desa Jebed Utara tahun 2020 yang berjumlah sebanyak 240 batita.)

Hasil hitungan rumus dengan $d$ (tingkat kepercayaan) 5\%, Z1- 22 (tingkat kepercayaan penelitian) $95 \%$ atau 1.96 dan $\mathrm{p}$ (proporsi kasus Stunting di kabupaten pemalang) $35,1 \%(0,351)$, maka minimal sampel penelitian adalah 103 batita. Metode pengambilan sampel pada penelitian ini menggunakan teknik simple random sampling. Penelitian ini dilaksanakan selama bulan Februari Maret 2020. Data yang dikumpulkan adalah data primer dengan metode wawancara dan pengamatan. Wawancara menggunakan daftar pertanyaan atau kuesioner. Data primer yang diperlukan dalam penelitian ini meliputi : nama, umur, jenis kelamin, tanggal lahir, tanggal survei, berat badan dan panjang badan serta kondisi perumahan. Variabel penelitian data, teknik pengumpulan data dan alat ukur penelitian meliputi: (1) menimbang berat badan batita yang menjadi responden ; (2) mengukur tinggi badan batita yang menjadi responden dengan microtoise atau infantometer; (3) mengisi kuesioner dengan mewawancarai ibu batita tentang karakteristik batita(Tanggal Lahir, Umur, Jenis Kelamin,) dan menanyakan Berat Badan dan Panjang Badan waktu lahir dengan mengcroschek dengan KMS dan mengisi lembar formulir penilaian rumah sehat dengan carawawancara dan observasi. Analisis data dengan menggunakan analisis univariat dan bivariate menggunakan uji chi square.

Hasil

\section{Hubungan berat badan lahir rendah (BBLR) dengan Stunting}

\begin{tabular}{|c|c|c|c|c|c|c|c|}
\hline \multirow[t]{3}{*}{ Variabel } & \multicolumn{4}{|c|}{ Kejadian stunting } & & & \multirow{3}{*}{$\begin{array}{l}\mathbf{P} \\
\text { value }\end{array}$} \\
\hline & \multicolumn{2}{|c|}{ Ya } & \multicolumn{2}{|c|}{ Tidak } & \multicolumn{2}{|c|}{ Total } & \\
\hline & $\overline{\mathbf{n}}$ & $\%$ & $\mathbf{n}$ & $\%$ & $\mathbf{N}$ & $\%$ & \\
\hline Berat Badan Lahir & & & & & & & $\mathbf{0 , 9 6 6}$ \\
\hline$<2500$ gram & 4 & $\begin{array}{l}17 \\
, 4\end{array}$ & 19 & $\begin{array}{l}82, \\
6\end{array}$ & 23 & $\begin{array}{l}10 \\
0\end{array}$ & \\
\hline$\geq 2.500$ gram & $\mathbf{8}$ & 10 & 72 & $\begin{array}{l}90, \\
0\end{array}$ & 80 & $\begin{array}{l}10 \\
0\end{array}$ & \\
\hline Jumlah & 12 & $\begin{array}{l}11 \\
, 7\end{array}$ & 91 & $\begin{array}{l}\text { 89, } \\
3\end{array}$ & 103 & $\begin{array}{l}10 \\
0\end{array}$ & \\
\hline
\end{tabular}

Tabel 1:Distribusi Berat Badan Lahir Menurut Kejadian Stunting Batita

Berdasarkan tabel tersebut diketahui bahwa dari 23 anak dengan berat badan lahir rendah terdapat 4 anak $(17,4 \%)$ yang stunting sedangkan dari 80 anak dengan berat badan lahir normal terdapat 8 anak $(10 \%)$ yang stunting. Perhitungan dengan menggunakan uji statistik khai kuadrat menghasilkan nilai p sebesar 0,966 (lebih besar dari nilai alpha

0,05). Dengan demikian hipotesis nol diterima yaitu tidak ada hubungan antara berat badan lahir dengan kejadian stunting anak batita di desa Jebed Utara Kecamatan Taman Kabupaten Pemalang 
2. Hubungan panjang badan lahir dengan Stunting

\begin{tabular}{|c|c|c|c|c|c|c|c|}
\hline \multirow{3}{*}{ Variabel } & \multicolumn{4}{|c|}{ Kejadian stunting } & & & \multirow{3}{*}{$\begin{array}{l}\mathbf{P} \\
\text { value }\end{array}$} \\
\hline & \multicolumn{2}{|c|}{ Ya } & \multicolumn{2}{|c|}{ Tidak } & \multicolumn{2}{|c|}{ Total } & \\
\hline & $\mathbf{n}$ & $\%$ & $\mathbf{n}$ & $\%$ & $\mathbf{N}$ & $\%$ & \\
\hline $\begin{array}{l}\text { Panjang Badan } \\
\text { Lahir }\end{array}$ & & & & & & & $\mathbf{0 , 0 0 0}$ \\
\hline$<48 \mathrm{~cm}$ & 5 & $\begin{array}{l}23, \\
8\end{array}$ & 16 & $\begin{array}{l}76, \\
2\end{array}$ & 21 & 100 & \\
\hline$\geq 48 \mathrm{~cm}$ & 7 & $\mathbf{8 , 5}$ & 75 & $\begin{array}{l}91, \\
5\end{array}$ & 82 & 100 & \\
\hline Jumlah & 12 & $\begin{array}{l}11, \\
7\end{array}$ & 91 & $\begin{array}{l}\mathbf{8 9} \\
\mathbf{3}\end{array}$ & 103 & 100 & \\
\hline
\end{tabular}

Tabel 2: Distribusi Panjang Badan Lahir Menurut Kejadian Stunting Batita

Dalam tabel 2 disajikan tabulasi silang antara variabel panjang badan lahir dan kejadian stunting anak usia 0-36 bulan di desa Jebed Utara tahun 2020. Berdasarkan tabel tersebut diketahui bahwa dari 21 anak dengan panjang badan lahir rendah terdapat 5 anak $(23,8 \%)$ yang stunting sedangkan dari 82 anak dengan panjang lahir normal terdapat 7 anak $(8,5 \%)$ yang stunting. Perhitungan dengan menggunakan uji statistik khai kuadrat menghasilkan nilai $\mathrm{p}$ sebesar 0,00 (lebih kecil dari nilai alpha 0,05). Dengan demikian hipotesis nol ditolak yaitu ada hubungan antara panjang badan lahir dengan kejadian stunting anak usia batita di desa Jebed Utara. Uji statistik juga menghasilkan nilai odds ratio (OR) yaitu 1,56 yang berarti bayi dengan panjang badan lahir rendah berisiko 1,56 kali menjadi stunting dibandingkan dengan bayi yang lahir normal.

\section{Pembahasan}

\section{Prevalensi Stunting}

Hasil penelitian menunjukkan bahwa prevalensi stunting (kategori pendek dan sangat pendek) pada anak usia
13-36 bulan di desa Jebed Utara adalah 11,7\%. Angka ini lebih rendah dari hasil survei Riskesdas 2018 Jawa Tengah sebesar $30 \%$ dan juga lebih rendah dari angka prevalensi nasional sebesar $37,2 \%$. Meskipun demikian berdasarkan kriteria penilaian tingkat keparahan stunting dari WHO, prevalensi stunting pada anak usia 13- 36 bulan di desa Jebed Utara pada tahun 2020 termasuk dalam kategori akut yaitu berada dalam range kurang dari 20 $\%$. Persentase stunting mencerminkan efek kumulatif dari kekurangan gizi dan infeksi sejak dini bahkan sebelum kelahiran. Oleh karena itu ukuran ini dapat diartikan sebagai indikasi kondisi lingkungan yang buruk atau hambatan pertumbuhan jangka panjang terhadap potensi pertumbuhan anak. Stunting memiliki konsekuensi jangka panjang untuk masa depan sumber daya manusia. Dengan demikian, mencegah stunting pada anak-anak sangat penting dilakukan untuk melindungi kemampuan belajar dan modal sumber daya manusia di masa depan. Asupan gizi yang tidak memadai adalah salah satu dari banyak penyebab stunting.

Kegagalan pertumbuhan sering dimulai sejak di dalam rahim dan terus berlangsung setelah lahir, sebagai refleksi dari praktek menyusui yang kurang tepat dan pemberian makanan pendamping ASI yang tidak memadai serta kontrol terhadap infeksi yang kurang memadai (Victoria, et al. 2010). Oleh karena itu, fokus pada jendela seribu hari pertama kehidupan yaitu sejak kehamilan sampai anak berusia dua tahun ulang tahun adalah sangat penting. Ada beberapa tindakan yang dapat dilakukan untuk mengurangi prevalensi stunting. Pertama, mengoptimalkan praktek menyusui yang dimulai dengan inisiasi dini dan 
dilanjutkan dengan pemberian ASI eksklusif selama enam bulan. Pemberian ASI yang tepat akan memberikan perlindungan terhadap infeksi gastrointestinal yang dapat menyebabkan deplesi nutrisi yang parah. Selain sebagai sumber utama nutrisi selama infeksi, pemberian ASI sampai tahun kedua memberikan kontribusi signifikan terhadap asupan gizi.

Kedua, intervensi yang paling efektif dalam mencegah stunting terutama pada masa pemberian makanan pendamping ASI yaitu setelah usia anak enam bulan adalah peningkatan kualitas makanan anak. Berbagai penelitian menunjukkan bahwa pemberian makanan yang bervariasi dan memberikan makanan bersumber hewani berhubungan dengan peningkatan pertumbuhan anak dan menurunkan stunting. Ketiga, karena stunting yang terjadi berkaitan dengan lingkungan, sosial ekonomi, dan budaya maka intervensi gizi secara langsung harus terintegrasi dengan intervensi sensitif seperti pencegahan infeksi melalui penyediaan air bersih dan peningkatan PHBS. Keterpaduan program gizi spesifik dan program gizi sensitif yang mampu mencapai ke sasaran sangat berkontribusi terhadap penurunan prevalensi stunting.

Hasil penelitian menunjukkan bahwa prevalensi panjang badan lahir rendah pada anak usia 13-36 bulan di desa Jebed Utara tahun 2020 sebesar 22,3\%. Angka ini sedikit lebih rendah dari angka Riskesdas 2018 dimana persentase panjang badan lahir rendah di Provinsi Jawa Tengah adalah 22,4\% tetapi lebih tinggi dari angka nasional yang berada pada 20,2\%. Panjang lahir bayi akan berdampak pada pertumbuhan selanjutnya, seperti terlihat pada hasil penelitian yang dilakukan di Kecamatan Pati Kabupaten Pati didapatkan hasil bahwa panjang badan lahir rendah adalah merupakan salah satu faktor risiko balita stunting usia 12-36 bulan bahwa bayi yang lahir dengan panjang lahir rendah memiliki risiko 2,8 kali mengalami stunting dibanding bayi dengan panjang lahir normal (Anugraheni \& Kartasurya, 2012). Hadi (2010) mengemukakan bahwa dampak dari stunting ini adalah tidak hanya pada fisik yang lebih pendek saja, tetapi juga pada fungsi kognitifnya. Di dalam kandungan, janin akan tumbuh dan berkembang melalui pertambahan berat dan panjang badan, perkembangan otak serta organ-organ lainnya seperti jantung, hati, dan ginjal. Janin mempunyai plastisitas yang tinggi, artinya janin akan dengan mudah menyesuaikan diri terhadap perubahan lingkungannya baik yang menguntungkan maupun yang merugikan pada saat itu. Sekali perubahan tersebut terjadi, maka tidak dapat kembali ke keadaan semula. Perubahan tersebut merupakan interaksi antara gen yang sudah dibawa sejak awal kehidupan, dengan lingkungan barunya. Pada saat dilahirkan, sebagian besar perubahan tersebut menetap atau selesai, kecuali beberapa fungsi, yaitu perkembangan otak dan imunitas, yang berlanjut sampai beberapa tahun pertama kehidupan bayi. Kekurangan gizi yang terjadi dalam kandungan dan awal kehidupan menyebabkan janin melakukan reaksi penyesuaian. Secara paralel penyesuaian tersebut meliputi perlambatan pertumbuhan dengan pengurangan jumlah dan pengembangan sel-sel tubuh termasuk sel otak dan organ tubuh lainnya. Hasil reaksi penyesuaian akibat kekurangan gizi di ekspresikan pada usia dewasa dalam bentuk tubuh yang pendek, rendahnya 
kemampuan kognitif atau kecerdasan sebagai akibat tidak optimalnya pertumbuhan dan perkembangan otak .

\section{Hubungan Berat Badan Lahir Rendah Dengan Kejadian Stunting}

Hasil penelitian ini menunjukkan bahwa tidak ada hubungan antara berat badan lahir dengan kejadian stunting anak usia batita di desa Jebed Utara. Tabel 1 menunjukan bahwa batita usia 13- 36 bulan yang stunting proporsinya tidak jauh berbeda antara bayi yang lahir BBLR dan bayi yang lahir normal yaitu $17,4 \%$ dan $10 \%$. Kondisi tersebut dapat terjadi karena dalam penelitian ini kejadian stunting diukur ketika anak sudah berumur 13-36 bulan sedangkan berat badan lahir diukur pada saat bayi lahir sehingga dalam kurun waktu tersebut bayi BBLR mempunyai waktu dan kesempatan yang cukup untuk tumbuh dan berkembang.

Hal ini dimungkinkan karena adanya berbagai program intervensi untuk peningkatan BBLR dari pemerintah maupun kepedulian masyarakat yang lebih baik dalam menangani masalah kekurangan berat badan pada anak. Berbagai upaya perbaikan gizi pada bayi khususnya utuk meningkatkan berat badan bayi tampaknya cukup berhasil sehingga dalam penelitian ini anak usia 1336 bulan yang tidak stunting proporsinya tidak jauh berbeda antara bayi yang lahir BBLR dan bayi yang lahir normal yaitu $76,8 \%$ dan $76,5 \%$. Terlebih lagi menurut Nainggolan (2019) menyebutkan bahwa bayi yang lahir dengan BBLR akan lebih cepat bertambah berat badanya seakanakan mengejar ketertinggalanya sedangkan bayi non BBLR umumnya sering tumbuh lambat hal ini diperkirakan oleh kualitas dan kuantitas makanan serta gangguan pencernaan. Jika anak dengan berat badan lahir rendah menerima asupan gizi yang adekuat makan pertumbuhan normal dapat terkejar (catch up). Jika pada 6 bulan awal balita dapat mengejar pertumbuhan, maka besar kemungkinan balita tersebut dapat tumbuh secara normal. Stunting merupakan status gizi yang didasarkan pada indeks panjang badan menurut umur (PB/U) sehingga berat badan tidak secara langsung berhubungan dengan indeks stunting. Meskipun demikian berat badan lahir yang merupakan karakteristik bayi tidak terpisahkan dengan panjang badan lahir sehingga berat lahir dapat mempengaruhi pertumbuhan tinggi badan anak khususnya pada awal periode neonatal.

Hasil penelitian ini sejalan dengan penelitian yang dilakukan oleh Gabrielisa dkk pada tahun 2017 menunjukan bahwa tidak terdapat hubungan antara berat badan lahir dengan kejadia stunting pada balita diwilayah kerja puskesmas Sonder Kabupaten Minahasa. Berbeda dengan hasil penelitian dari Nainggolan, 2019 yang menyatakan bahwa ada hubungan yang signifikan antara hubungan berat badan lahir rendah dengan kejadian stunting pada anak. Nilai prevalence ratio yang diperoleh sebesar 25,5 yang artinya, bayi yang mengalami BBLR mempunyai resiko 25 kali untuk mengalami stunting di bandingkan dengan bayi yang berat badan lahir normal.

\section{Hubungan Panjang Badan Lahir dengan Kejadian Stunting}

Hasil penelitian ini menunjukkan ada hubungan antara panjang badan lahir dengan kejadian stunting anak usia batita 
bulan di desa Jebed Utara. Tabel 2 menunjukan bahwa proporsi balita usia batita yang lahir pendek dan stunting sebesar 23,8 \% padahal prevalensi stunting pada bayi baru lahir dalam penelitian ini diketahui sebesar $11,7 \%$.

Adanya pengaruh faktor pasca kelahiran terhadap panjang badan anak tampaknya terlihat dengan makin menurunnya z-skor $\mathrm{PB} / \mathrm{U}$ seiring bertambahnya usia. Stunting pada usia 13-36 bulan yang meningkat selain disebabkan karena catch up growth yang tidak memadai pada bayi lahir pendek juga karena ketidakcukupan asupan zat gizi pada bayi lahir normal yang menyebabkan terjadinya growth faltering (gagal tumbuh). Asupan gizi yang rendah serta paparan terhadap infeksi memberikan dampak growth faltering yang lebih berat pada batita normal. Hal ini sejalan penelitian yang telah dilakukan Anugraheni, H.S., \& Kartasurya, M. I. (2012) menyatakan bahwa salah satu faktor yang berpengaruh signifikan terhadap kejadian stunting adalah penyakit infeksi. Anak mengalami stunting, disebabkan karena pada saat didalam kandungan anak sudah mengalami retardasi pertumbuhan atau pertumbuhan yang terhambat saat masih didalam kandungan (Intra Uterine Growth Retardation/IUGR). IUGR ini disebabkan oleh kemiskinan, penyakit dan defisiensi zat gizi. Artinya ibu dengan dengan gizi kurang sejak trimester awal sampai akhir kehamilan akan melahirkan BBLR, yang kedepannya anak akan beresiko besar menjadi stunting

Anak-anak yang mengalami stunting lebih awal yaitu sebelum usia enam bulan, akan mengalami stunting lebih berat menjelang usia dua tahun.
Stunting yang parah pada anak-anak mengakibatkan terjadinya penurunan kemampuan perkembangan fisik dan mental sehingga ia tidak mampu belajar optimal di sekolah, dibandingkan anakanak bertinggi badan normal. Anak dengan stunting juga berisiko memiliki IQ 5-10 poin lebih rendah dibanding dengan anak normal. Selain itu, stunting pada balita juga berisiko meningkatkan angka kematian pada anak, menurunkan kemampuan kognitifnya, perkembangan motorik anak rendah, serta fungsi tubuh yang tidak seimbang. Penelitian dari Achadi (2012) juga menunjukkan bahwa stunting pada batita berhubungan dengan keterlambatan perkembangan bahasa dan motorik halus dan stunting yang terjadi pada usia 36 bulan pertama biasanya disertai efek jangka panjang seperti berisiko tinggi menderita penyakit kronik, seperti obesitas, mengalami gangguan intolerans glukosa, hipertensi ataupun penyakit jantung koroner dan osteoporosis. Menyadari akan dampak stunting yang begitu serius sebenarnya pemerintah dan masyarakat sudah mulai lakukan upaya pencegahan dan penanggulangan misalnya melalui gerakan 1.000 hari pertama kehidupan dengan berbagai kegiatan seperti penyuluhan gizi, suplementasi gizi pada bayi dan balita, hingga suplementasi pada ibu hamil.

\section{Simpulan}

Hasil penelitian menyimpulkan bahwa prevalensi stunting pada anak usia batita di desa Jebed Utara adalah 11,7\%, prevalensi BBLR pada anak usia batita di desa jebed utara tahun 2020 adalah $23,8 \%$ dan prevalensi panjang lahir rendah pada anak usia batita di desa Jebed Utara tahun 2020 adalah 20,4\%. Hasil analisis statistik lanjutan menyimpulkan tidak ada 
hubungan antara berat badan lahir dengan kejadian stunting pada anak usia batita di desa jebed utara tahun 2020 dan ada hubungan antara panjang badan lahir dengan kejadian stunting pada anak usia batita di desa jebed utara tahun 2020. Berdasarkan penelitian tersebut peneliti menyarankan kepada Dinas Kesehatan agar dapat meningkatkan upaya pemantauan pertumbuhan Balita khususnya bayi dengan panjang lahir pendek dengan melakukan pengukuran secara berkala panjang badan anak yang pelaksanaannya diintegrasikan dalam kegiatan penimbangan Balita di Posyandu. Selain itu perlu juga penguatan upaya pencegahan terjadinya kelahiran bayi pendek dengan cara memberikan perhatian yang lebih besar pada programprogram perbaikan gizi ibu dan pengadaan posyandu remaja bagi para calon ibu yang harapanya bisa mempersiapkan calon generasi yang lebih sehat.

\section{Daftar Pustaka}

Anugraheni HS \& Kartasurya MI. 2012. Faktor Risiko Kejadian Stunting Pada Anak Usia 12-36 Bulan Di Kecamatan Pati, Kabupaten Pati. Program Studi Ilmu Gizi Fakultass Kedokteran Universitas Diponegoro. Journal of Nutrition College, Volume 1, Nomor 1, Tahun 2012, Hal : $590-605$.

Brinkman HJ, de Pee S, \& Sanogo I., 2010. High Food Prices and The Global Financial Crisis Have Reduced Access to Nutritious Food and Worsened
Nutritional Status and Health. J. Nut, 140, 153S-161S

Badan Litbangkes Kemenkes. 2019. Riset kesehatan dasar (Riskesdas) tahun 2018. Jakarta: Badan Litbangkes Kemenkes RI.

Cesar, G.V., Linda, A., Caroline, F., Pedro, C.H., \& Reyna. (2008, January 26). Maternal and child undernutrition: consequences for adult health and human capital. Lancet, Published, 6(07), 616924. doi:DOI: 10.1016/S01406736(0761692-4

Diafrilia, M.I. (2014). Determinan stunting pada anak umur 24-59 bulan di wilayah kerja Puskesmas Ranomuut Kecamatan Paldua. Skripsi. FKM Universitas Sam Ratulangi.

FAO, IFAD, \& WFP. (2013). The state of food insecurity in the world 2013. The multiple dimension of food security. Retrieved from http://www.fao.org/docrep/pdf. Rome: Food and Agriculture Organization of the United Nations. Diakses August 21, 2016

Fitri, L. 2018. Hubungan BBLR dan Asi Ekslusif dengan Kejadian Stunting di Puskesmas Lima Puluh Pekanbaru. Jurnal Endurance 3(1) Februari 2018 (131-137). Diakses di https://ejournal.kopertis10.or.id/ index.php /endurance /article/view/1767 pada tanggal 25 September 2019. 
Kemenkes RI. (2018). Umur sama, tinggi badan berbeda. Dirjen bina gizi dan KIA Kemenkes RI. Retrieved Februari 10, 2016, from

http://www.gizikia.depkes.go.id/ terbitan/umur-sama-tinggibadan-berbeda/

Kramer, M.S. \& Kakuma R. (2012). Optimal duration of exclusive breastfeeding. doi:10.1002/14651858. CD003517.pub2.

Krebs, N.F., Mazariegos, M., Tshefu, A., Bose, C., Sami, N., \& Chomba, E. (2011). Complementary feeding study group meat consumption is associated with less stunting among toddlers in four diverse low-income settings. 32, 91-185.

Kusharisupeni. (2014). Growth faltering pada bayi di kabupaten Indramayu Jawa Barat.

Margawati, A. (2012). Faktor kejadian stunting pada balita usia 24-36 bulan di Kecamatan Semarang Timur. Journal of nutrition collage, 1(1), 715-730.

Nadiyah; Briawan, D.; Martianto, D., 2014. Faktor risiko stunting pada anak usia 0-23 bulan di Provinsi Bali, Jawa Barat, dan Nusa Tenggara Timur (NTT). Jurnal Gizi dan Pangan, Juli 2014, 9(2): 125-132

Nianggolan., 2019. Hubungan berat badan lahir rendah dengan kejadian stunting pada anak usia 1-3 tahun. Nutrik Jurnal vol. 3 nomor 1 April 2019. Diakses pada 10 Maret 2020.

Novianti Tysmala Dewi, Dhenok Widari. (2018). Hubungan Berat Badan Lahir Rendah dan penyakit infeksi dengan kejadian stunting pada baduta di Desa Maron Kidul Kecamatan Maron Kabupaten Probolinggo. Jurnal Kesehatan UNAIR. 9(2), 2632

Onyango, A., Borghi , E., de Onis M, Casanovas, M., \& Garza, C. (2013). Complementary feeding and attained linear growth among 6-23 month old children. Public health nutr. doi:10.1017/S1368980013002401

Proverawati, A \& Ismawati, C. (2010). Berat badan lahir rendah . Yogyakarta: Muha medika.

Rahmadi, A. (2016). Hubungan berat dan panjang badan lahir dengan kejadian stunting anak 12-59 Bulan di Provinsi Lampung (Analisis Data Sekunder Survei Pemantauan Status Gizi Provinsi Lampung Tahun 2015. Jurnal Kesehatan Metro Sai Wawai. 9(2), 26-32.

Notoatmodjo, S. (2018). Metodologi penelitian kesehatan. Jakarta: PT. Rineka Cipta.

Supariasa, B.B. \& Fajar. (2012). Penilaian status gizi. Jakarta: EGC.

Setiawan, E, Machmud, R, dan Masrul. 2018. Faktor-faktor yang Berhubungan dengan Kejadian 
Stunting pada Anak Usia 24-59

Bulan di Wilayah Kerja Puskesmas Andalas Kecamatan Padang Timur Kota Padang Tahun 2018. Jurnal Kesehatan Andalas. Diakses dari: http://jurnal.fk.unand.ac.id pada 19 September 2020.

Tim Nasional Percepatan Penanggulangan Kemiskinan(tnp2k). 2019 . 100 Kabupaten atau kota Prioritas untuk anak kerdil (Stunting)

Torlesse, H., Cronin , A., Sebayang, S., \& Nandy, R. (2016). Determinants of stunting in Indonesia children : evidence from a croos-sectional survey indicate a prominent role for the water, sanitation, and hygiene sector in stunting reduction. BMC public healt 16:669. UNICEF. (2013). Improving child nutrition, the achievable imperative for global progress. United Nations Children's Fund. New York: UNICEF .

WHO. 2018. Levels and Trends in Child Malnutrition: Key findings of the 2018 Edition of the Joint Child Malnutrition Estimates. Diakses dari: www.who.int/nutgrowthdb pada tanggal 23 September 2020 .

Wiyogowati, C. (2012). Kejadian stunting pada anak berumur dibawah lima tahun (0-5 bulan) di Provinsi Papua Barat tahun 2010 (Analisis data riskesdas tahun 2010). Skripsi. Fakultas kesehatan masyarakat Universitas Indonesia, Depok 